ScIDice
International Journal of Dentistry and Oral Science (IJDOS)

ISSN: $2377-8075$

\title{
An Overview On Oral Manifestations Of Covid-19
}

\section{Research Article}

John Abraham ${ }^{1 *}$

Department of Family Medicine/Geriatrics, Marathahalli-Sarjapur Rd, beside Bank of Baroda, John Nagar, Koramangala, Bengaluru, Karnataka 560034 India.

\section{Abstract}

Background: Severe Acute Respiratory Syndrome CoronaVirus-2 (SARS-CoV-2) or COVID-19 was characterized as a pandemic before been declared asa Public Health Emergency of International Concern (PHEIC). The outbreak has affected more than 148 million people affecting the respiratory system, skin, and digestive system. Hence, the present study aims tofind the preponderance of oral manifestations of COVID-19and to suggest the management of those affected with the same.

Method: In the present review, search engines such as PubMed, Scopus, ScienceDirect, and Web of Science were used. Gray literature was also included by performing a manual search on Google Scholar. All the articles that were published till April 25, 2021, were included. The search keywords include: "Symptoms", "Oral Manifestation", "Mouth disease", "COVID-19", "SARS-CoV-2", and "India".

Results: The most common oral manifestations are: sore throat $(25.43 \%)$ followed by dysgeusia $(27.84 \%)$. The other common symptoms are enanthema (58.5\%), oral lesions (48.5\%), and oral bleeding (22.95\%). Chlorhexidine mouthwash, topical or systemic corticosteroids,normal saline gargling, and artificial saliva are used in managing the manifestations.

Conclusion: Looking out and identifyingthe oral manifestation can help in timely diagnosis and treatment of COVID-19.So, Therefore, it is important to include dentists in the multi-disciplinary team assisting the COVID- 19 patients.

Keywords: SARS-CoV-2; COVID-19; Oral Manifestation; Management.

\section{Introduction}

Severe Acute Respiratory Syndrome CoronaVirus-2 (SARSCoV-2) or COVID-19, were at the start, reported in December 2019 by the officials in Wuhan City, China (WHO, 2020-a). Concerned by the continuous rise in the cases, WHO on March 11, 2020, assessed the situation could be characterized as a pandemic before declaring the outburst as a Public Health Emergency of International Concern (PHEIC) on April 27, 2020 (WHO, 2020b). The outbreak has affected more than 148 million people causing more than 3.1 million deaths worldwide (WHO, n.d.). Commonly seen symptoms include fever, dry cough, and fatigue, loss of taste or smell, diarrhea, nasal congestion, nausea or vomiting, headache, chills or dizziness, conjunctivitis different types of skin rashes, sore throat, and muscle or joint pain (WHO, 2020-c).

As with any other viruses, COVID-19 is also evolving overtime, resulting in thousands of mutations (WHO, 2021). The three widely known mutations are B.1.1.7 (first reported in the United
Kingdom), B.1.351 (first reported in South Africa), and P.1 (first reported in Brazil) ("How Many New Coronavirus," 2021). The United States has discovered about 677 mutants whereas India has detected over 24,000 mutants in 7,000 variants (Haseltine, 2021; IANS, 2021).

\section{Pathogenesis}

In early infection, SARS-CoV2 attacks specific cells like bronchial epithelial,nasal cells and pneumocytes. This is mainly via the viral structural spike(S) protein that binds to the angiotensin-converting enzyme 2 (ACE2) receptor. Corona virus entry into the host cells is mediated by SARS- CoV2 S protein which is activated by cleavage of ACE2. Also, The viral uptake is upgraded by, Type 2 trans-membrane Serine Protease (TMPRSS2) existing in the host cells.

SARS-CoV-2 infects and destroys the T lymphocytes. The viral inflammatory response, impedes lymphopoiesis and enhances lym-

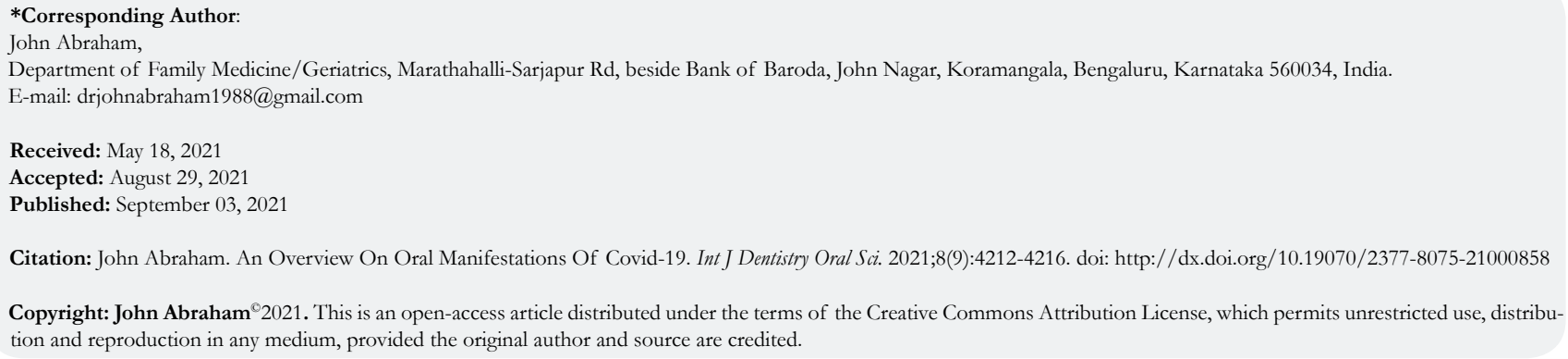

Copyright: John Abraham 2021. This is an open-access article distributed under the terms of the Creative Commons Attribution License, which permits unrestricted use, distribution and reproduction in any medium, provided the original author and source are credited. 
phocyte apoptosis.During later stages of viral infection, especially when viral replication is rushed, epithelial-endothelial barrier integrity is found to be compromised. Also, dysfunctional alveolarcapillary oxygen transmission, and diminished oxygen diffusion capacity is caused due to bradykinin-dependent lung angioedema. When COVID-19 infection is severe, the immediate activation of coagulation and exhaution of clotting factors occurs in inflamed lung tissues and pulmonary endothelial cells may result in microthrombi formation and contribute to the thrombotic complications, such as deep venous thrombosis, pulmonary embolism stroke and Myocardial Infarctions.

Concerning to the oral cavity, prescence of ACE2 in the cells of oral mucosa and tongue, indicates that the mouth is likely infectious route of SARS CoV2 and therefore advocates an a relatedness between this viral infections and oral ulcers associated with COVID-19.

Clinical features:The newer variants of COVID-19 have a wide range of symptoms and medical complications (ANI, 2021). The primary symptoms of the variants include fever, muscle pain, loss of smell and taste, and dry and persistent cough. The additional symptoms which is seldom found include conjunctivitis, sore throat, headache, rashes, upset stomach, and discoloration of fingers and toes (Pandey, 2021).

Oral Manifestations: According to Froum (2020), physicians are examining the direct connection between COVID-19 and oral disease, as the survivors who battled against the disease for weeks to months, found a decline in their oral health resulting in sensitive gums, teeth cracking, teeth falling out, and teeth turning grey. Some studies suggest that the mouth might be the most vulnerable area to the virus because of the abundant Angiotensin Converting Enzyme (ACE2) receptors found in the oral tissue. The common oral manifestations associated with COVID-19 are gingival inflammation, xerostomia (dry mouth), oral ulcerations and gingival tissue breakdown, and loss of taste and smell. Thus considering the importance of oral health and the relationship between oral health and COVID-19, the present study aimed at examining out the prevalence of oral manifestations of COVID-19 and the suggested management.

\section{Method}

\section{Information search}

Electronic search engines such as PubMed, Scopus, ScienceDirect, and Web of Science were used. To access the gray literature, a manual search was performed on Google Scholar. All the articles that were published till April 25, 2021, were included.

The search keywords include: "Symptoms", "Oral Manifestation”, "Mouth disease", "COVID-19", "SARS-CoV-2", and "India".

\section{Study selection}

Those studies which included oral manifestation of COVID-19, preferably in prevalence, and those which included details about management at different levels were included in this review.

\section{Inclusion and exclusion criteria}

The studies which were published on oral manifestations with the percentage indicated, preferably in the Indian context were included in the review. Studies that were published in languages other than English were excluded from the review.

\section{Analysis}

Author(s), year of publication, type of publication, country where the study was done, different types of oral manifestations, and the methods used to manage the symptoms were collected for the present review. Frequencies, the average (mean), largest observation (maximum), and smallest observation (minimum) were calculated from the available data.

\section{Result}

The present review sampled 22 papers which include 13 research articles, 7 review articles, 1 short communication, and 1 general article.

As shown in table 1, most of the papers were published in 2020 $(63.6 \%)$ while the rest were published in 2021 (36.4\%). More than

Table 1. Characteristics of the studies.

\begin{tabular}{|c|c|c|c|}
\hline & & $\mathrm{N}$ & $\%$ \\
\hline Year & 2020 & 14 & $63.60 \%$ \\
& 2021 & 8 & $36.40 \%$ \\
\hline Country & India & 8 & $53.30 \%$ \\
& The United States & 2 & $13.30 \%$ \\
& Singapore & 1 & $6.70 \%$ \\
& Israel & 1 & $6.70 \%$ \\
& Brazil & 1 & $6.70 \%$ \\
& France & 1 & $6.70 \%$ \\
& Unknown & 1 & $6.70 \%$ \\
\hline Type of publication & Research articles & 13 & $59.10 \%$ \\
& Review articles & 7 & $31.82 \%$ \\
& Short communication & 1 & $4.54 \%$ \\
& Article & 1 & $4.54 \%$ \\
\hline
\end{tabular}


Table 2. Prevalence of the oral manifestations in COVID-19 diagnosed.

\begin{tabular}{|c|c|c|c|c|}
\hline & N & Mean & Maximum & Minimum \\
\hline Papers with prevalence & 10 & & & \\
\hline Sore throat & 9 & 25.43 & 58.9 & 9.8 \\
\hline Dysgeusia & 5 & 27.84 & 39.3 & 10.5 \\
\hline Enanthema & 2 & 58.5 & 88 & 29 \\
\hline Oral lesions & 2 & 48.5 & 68 & 29 \\
\hline Oral bleeding & 2 & 22.95 & 41.2 & 4.7 \\
\hline
\end{tabular}

Table 3. Descriptive characteristics of the studies included.

\begin{tabular}{|c|c|c|c|c|c|}
\hline Sl.No & Author(s) \& Year & Country & Type of publication & Major Findings & Management \\
\hline 1 & $\begin{array}{l}\text { Kumar, S., Rathore, P., Choudhary, N., } \\
\text { Singh, N., et al (2020) }\end{array}$ & India & Research article & $\begin{array}{l}\text { 1. Sore throat: } 14 \% \text { in both }-16-30 \text { years and } 31-45 \text { years, } 9 \% \\
\text { in } 46-60 \text { years. } \\
\text { 2. Expectoration: } 2 \% \text { in }>60 \text { years. }\end{array}$ & \\
\hline 3 & $\begin{array}{l}\text { Yadav, V., Bhagat, S., Sharma, D. K., } \\
\quad \text { Sibia, R. P. S., et al (2021) }\end{array}$ & India & Research article & $\begin{array}{c}\text { Dysgeusia - } 13.1 \% \\
\text { Dryness of throat }-10.5 \% \text { Soreness of throat }-9.8 \% \text { Posterior } \\
\text { nasal discharge }-5.2 \%\end{array}$ & \\
\hline 4 & $\begin{array}{l}\text { Biadsee, A., Biadsee, A., Kassem, F., } \\
\text { Dagan, O., et al (2020) }\end{array}$ & Israel & Research article & $\begin{array}{c}\text { Impaired sense of taste - } 38.3 \%(49) \\
\text { Sore throat - } 26.6 \%(34) \\
\text { Dry mouth - } 56.3 \%(72) \text { Plaque-like changes in the tongue - } \\
7 \%(9) \\
\text { Swelling: oral cavity - } 7.8 \%(10) \text {, palate - } 3.1 \%(4) \text {, tongue - } \\
3.1 \%(4) \text {, gums - } 1.6 \%(2) \text { Current oral bleeding - } 4.7 \%(6)\end{array}$ & \\
\hline 5 & $\begin{array}{l}\text { Goel, N., Spalgais, S., Mrigpuri, P., } \\
\text { Khanna, M., et al (2020) }\end{array}$ & India & Research article & Sore throat $-14.9 \%(5)$ & \\
\hline 6 & $\begin{array}{l}\text { Gupta, V., Rajanna, L. B., Upadhyay, K., } \\
\text { Bhatia, R., et al (2021) }\end{array}$ & India & Research article & $\begin{array}{c}\text { Sore throat - } 58.9 \% \text { Gustatory Dysfunction (sense of taste) } \\
\qquad-39.53 \%\end{array}$ & \\
\hline 7 & $\begin{array}{l}\text { Sahoo, P. R., Sahu, M., Surapaneni, P. S., } \\
\text { Maiti, A., et al (2021) }\end{array}$ & India & Research article & $\begin{array}{c}\text { Altered taste }-10.5 \%(76) \text { Throat pain }-14.2 \%(102 \text { [combined] }) \\
\text { The prevalence of altered taste was much lower compared to } \\
\text { Europeans and similar to East Asians. }\end{array}$ & \\
\hline 8 & $\begin{array}{l}\text { Iranmanesh, B., Khalili, M., Amiri, R., } \\
\text { Zartab, H., et al (2020) }\end{array}$ & & Review paper & $\begin{array}{l}\text { 1. Oral manifestations included macule, papule, pustule, plaque, } \\
\text {,erosion, ulcer, hemorrhagic crust, petechiae, erythema, } \\
\text { fissured or depapillated tongue, pigmentation, and halitosis } \\
\text { 2. The most common sites of involvement is tongue ( } 38 \%) \text {,fol- } \\
\text { lowed by labial mucosa }(26 \%) \text {, palate }(22 \%) \text {, gingiva }(8 \%) \text {, } \\
\text { buccal mucosa }(5 \%) \text {, oropharynx }(4 \%) \text {, and tonsil }(1 \%) \text {. } \\
\text { 3. Oral lesions were painful, with burning sensation, or pruritus) } \\
\text { in } 68 \% \text { of the cases. } \\
\text { 4. Swelling of oral cavity (including palatal, lingual, and alveolar } \\
\text { mucosa) was reported by } 8 \% \text { of the patients. } 5 \text {. Enanthema was } \\
\text { reported in } 29 \% \text { COVID-19 confirmed cases in a study }\end{array}$ & $\begin{array}{l}\text { Different types of therapies including } \\
\text { chlorhexidine mouthwash, nystatin, } \\
\text { oral fluconazole, topical or systemic } \\
\text { corticosteroids, systemic antibiotics, } \\
\text { systemic acyclovir, artificial saliva, and } \\
\text { photobiomodulation therapy (PBMT) } \\
\text { were prescribed for oral lesions depending } \\
\text { on the etiology. }\end{array}$ \\
\hline 9 & $\begin{array}{l}\text { Gupta, S., Mohindra, R., Chauhan, P. K., } \\
\text { Singla, V., et al (2020) }\end{array}$ & India & Research article & $\begin{array}{c}\text { Oral findings - } 51.51 \% \\
\text { Sore throat }-39.4 \% \\
\text { Ageusia - } 5.9 \% \\
\text { Petachiae }-5.9 \% \\
\text { Gingival recession }-5.9 \% \\
\text { Gingival erythema - } 47.1 \% \\
\text { Dental caries - } 35.3 \% \\
\text { Perioral swelling - } 23.5 \% \\
\text { Gingival bleeding - } 41.2 \% \\
\text { Only ageusia, petechiae, and perioral swelling were found to be } \\
\text { associated with COVID-19 }\end{array}$ & \\
\hline 10 & $\begin{array}{c}\text { Drago, F., Ciccarese, G., Merlo, G., Trave, } \\
\text { I., et al (2021) }\end{array}$ & & Review paper & $\begin{array}{l}\text { Oropharyngeal mucosa - was reported by only a few patients } \\
\text { Painful oropharyngeal ulcers were reported. } 5 \text { cases) } \\
\text { Blisters and gingivitis - } 1 \text { case palatal petechiae, erythema, and } \\
\quad \text { pustules ( } 2 \text { cases) } \\
\text { 29\% of } 21 \text { Spanish patients were found to have oral-pharyngeal } \\
\quad \text { lesions. } \\
88 \% \text { of patients with enanthems with petechial pattern was } \\
\text { found to be strongly associated with COVID-19 }\end{array}$ & \\
\hline 11 & Singh, C. V., Jain, S., \& Parveen, S. (2021) & India & Research article & $\begin{array}{l}\text { For anosmia and dysgeusia caused due to the disease, use of } \\
\text { fluticasone nasal spray and triamcinolone medication was } \\
\text { reported with the recuperation of smell and the taste sensation } \\
\text { within a week. }\end{array}$ & $\begin{array}{l}\text { Gustatory dysfunction was treated triam- } \\
\text { cinolone paste TDS, normal saline gargle. }\end{array}$ \\
\hline 12 & $\begin{array}{l}\text { Singh, G., Priya, H., Mishra, D., et al } \\
\qquad(2021)\end{array}$ & & Review paper & $\begin{array}{c}\text { Common manifestations include - ageusia, non-specific anos- } \\
\text { mia (not associated with rhinitis), and hyposalivation. } \\
\text { Other symptoms include ulcers in the oral cavity, desquamative } \\
\text { gingivitis, herpetiform ulcers on attached gingiva, blisters/ } \\
\text { irregular ulcers on the tongue's dorsal surface, enlargement of } \\
\text { submandibular glands, and cervical lymphadenopathy. } \\
\text { Dysgeusia or ageusis and anosmia are frequent in COVID-19 } \\
\text { and varies from } 5.6 \% \text { to } 88.8 \%\end{array}$ & \\
\hline 13 & $\begin{array}{l}\text { Halepas, S., Lee, K. C., Myers, A., Yoon, } \\
\text { R. K., et al (2020) }\end{array}$ & $\begin{array}{l}\text { The Unit- } \\
\text { ed States }\end{array}$ & & $\begin{array}{c}23 \text { patients }(48.9 \%) \text { were presented with erythematous lips and/ } \\
\text { or angioedema while only } 5(10.6 \%) \text { were noted to have a straw- } \\
\text { berry tongue. Oral or oropharyngeal findings were significantly } \\
\text { associated with the presence of systemic rash }(\mathrm{p}=0.04) \text { and } \\
\text { conjunctivitis }(\mathrm{p}=0.02) \text {. } \\
\text { Cervical lymphadenopathy- } 19.2 \%\end{array}$ & \\
\hline
\end{tabular}




\begin{tabular}{|c|c|c|c|c|c|}
\hline \multirow{2}{*}{14} & \multirow{2}{*}{$\begin{array}{l}\text { Dos Santos, J. A., Normando, A. G. C., } \\
\text { da Silva, R. L. C., De Paula, R. M., et } \\
\text { al (2020) }\end{array}$} & \multirow{2}{*}{ Brazil } & \multirow{2}{*}{ Research article } & \multirow{2}{*}{$\begin{array}{c}\text { Symptoms: } \\
\text { Hypogeusia } \\
\text { White plaque and multiple pinpoint ulcers resembling the late } \\
\text { stage of herpetic lesions were found on the dorsum of the } \\
\text { tongue } \\
\text { Reactive lesion (fibroma) of approximately } 1 \mathrm{~cm}\end{array}$} & $\begin{array}{l}\text { Was treated with: Intravenous Fluconazole } \\
\text { (Zoltec } 200 \mathrm{mg} / 100 \mathrm{~mL} \text {, for ten days) } \\
\text { and oral nystatin ( } 100,000 \mathrm{IU} / \mathrm{mL}, 8 / 8 \mathrm{~h} \text {, } \\
\text { for } 30 \text { days), }\end{array}$ \\
\hline & & & & & $\begin{array}{l}\text { Antifungals and chlorhexidine digluconate } \\
(0.12 \%) \text { alcohol-free mouth rinses, and } \\
\text { daily applications of } 1 \% \text { hydrogen perox- } \\
\text { ide showed almost complete resolution. }\end{array}$ \\
\hline 15 & $\begin{array}{l}\text { Amorim dos Santos, J., Normando, A. G. } \\
\text { C., Carvalho da Silva, R. L., Acevedo, A. } \\
\text { C., et al (2020) }\end{array}$ & & Review paper & $\begin{array}{c}\text { Gustatory impairment - } 45 \% \\
\text { Dysgeusia - } 38 \% \\
\text { Hypogeusia - } 35 \% \\
\text { Ageusia - } 24 \% \\
\text { Tongue, palate, lips, gingiva, and buccal mucosa were affected } \\
\text { with irregular ulcers and petechiae. }\end{array}$ & \\
\hline 16 & $\begin{array}{l}\text { Chaux-Bodard, A. G., Deneuve, S., } \\
\text { \&Desoutter, A.(2020) }\end{array}$ & France & Research article & $\begin{array}{l}\text { Inflammation of a tongue papilla that may be accompanied by } \\
\text { pain and developmemt of erythematous macule within } 24 \text { hours } \\
\text {, which advances into irregular ulcer. }\end{array}$ & \\
\hline 17 & $\begin{array}{l}\text { Halboub, E., Al-Maweri, S. A., Alanazi, } \\
\text { R. H., Qaid, N. M., et al (2020) }\end{array}$ & & Review paper & $\begin{array}{l}\text { The most common orofacial manifestations were vesiculob- } \\
\text { ullous ulcerative lesions, and acute sialadentitis of the parotid } \\
\text { gland . In four cases, oral manifestations were the first signs of } \\
\text { COVID-19. }\end{array}$ & $\begin{array}{l}\text { The management of oral mucosal lesions } \\
\text { included one or more of the following: } \\
\text { topical or systemic corticosteroids, } \\
\text { diphenhydramine, mouthwashes, and anti- } \\
\text { biotics. In all cases, the reported orofacial } \\
\text { manifestations completely resolved within } \\
\text { a couple of days (range: } 3-21 \text { days) from } \\
\text { the day of diagnosis. }\end{array}$ \\
\hline \multirow[b]{2}{*}{18} & \multirow[b]{2}{*}{ Corchuelo, J., \& Ulloa, F. C. (2020) } & \multirow[b]{2}{*}{$\begin{array}{l}\text { The Unit- } \\
\text { ed States }\end{array}$} & \multirow[b]{2}{*}{ Research article } & \multirow[b]{2}{*}{$\begin{array}{l}\text { Symptoms: } \\
\text { Mild candidiasis in the posterior tongue } \\
\text { Painless petechiae }\end{array}$} & $\begin{array}{l}\text { Nystatin Oral Suspension was used with a } \\
\text { dose of } 3 \mathrm{ml} \text { ( } 300,000 \text { international units) } \\
\text { every } 6 \text { hours. }\end{array}$ \\
\hline & & & & & $\begin{array}{l}\text { Rinses with chlorhexidine (Chlorhexidine } \\
\text { gluconate } 0.12 \% \text { ) patient was instructed to } \\
\text { immerse the tooth brush brush in sodium } \\
\text { hypochlorite solution (1:100 dilution of } \\
5 \% \text { sodium hypochlorite) for } 30 \text { min, then } \\
\text { to rinse with water. }\end{array}$ \\
\hline 19 & $\begin{array}{l}\text { Mortazavi, H., Rezaeifar, K., \&Nastaba- } \\
\text { di, N. (2020) }\end{array}$ & & Mini-review paper & $\begin{array}{l}\text { Salivary gland disease } \\
\text { Xerostomia } \\
\text { Taste/smell alterations } \\
\text { Oral mucosal lesions }\end{array}$ & \\
\hline 20 & $\begin{array}{l}\text { La Rosa, G. R. M., Libra, M., De } \\
\text { Pasquale, R., Ferlito, S., et al (2021) }\end{array}$ & & Review paper & $\begin{array}{l}\text { Various oral lesions associated with COVID-19, includes, aph- } \\
\text { thous-like ulcerations and macules. The tongue, lips, and palate } \\
\text { were the most frequently affected sites. } \\
\text { The lesions could be related to the direct or indirect effect } \\
\text { of SARS-CoV-2 over the oral mucosa cells, and coinfections, } \\
\text { caused due to compromised immunity. }\end{array}$ & \\
\hline 21 & Stefania, D.M., (2020) & & Short communication & $\begin{array}{c}\text { Widespread clinical signs: } \\
\text { Enanthema of the mouth mucosa, presenting point-like blisters } \\
\text { surrounded by an erythematous halo. } \\
\text { In some cases, foot-and-mouth-like injuries have been found } \\
\text { in the intra-oral mucosa starting as widespread small } 1-2 \mathrm{~mm} \\
\text { spots which in a few days are joined together to form a single } \\
\text { ulcer covered by pseudo-membranes on the lip surface. The } \\
\text { lips appear swollen, chapped, and covered by bleeding eschars } \\
\text { turning necrotic, clearly bordered by hard erythematous tissue } \\
\text { and fibrin. }\end{array}$ & \\
\hline 22 & Karunakaran (2021) & & Article & $\begin{array}{c}\text { Multiple palatal and oropharyngeal petechial lesions } \\
\text { Dysgeusia Palatal and oropharyngeal erosions and ulcerative } \\
\text { lesions } \\
\text { Excessive salivation } \\
\text { Severe pain over the lesion area } \\
\text { Partial paresthesia surrounding the lesions } \\
\text { Irregular areas of blanching involving the palate } \\
\text { Burning sensation of palate and oropharynx, and dysphagia } \\
\text { Palatal and oropharyngeal tenderness and soreness } \\
\text { Necrotic pseudo membranes covering the erosive/ulcerative } \\
\text { lesions }\end{array}$ & $\begin{array}{l}\text { 1. Topical triamcinolone acetonide (Ke- } \\
\text { nacort) } 0.1 \% \text { paste (applied by the patient } \\
\text { three times daily) } \\
\text { 2. Doxycycline and benzalkonium chloride } \\
\text { mouthrinses (applied by the patient three } \\
\text { times daily) } \\
\text { 3. Topical benzocaine } 5 \% \text { gel (applied by } \\
\text { the patient three times daily) }\end{array}$ \\
\hline
\end{tabular}

half the papers sampled the Indian population (53.3\%) followed by The United States $(13.3 \%)$.

As shown in table 2 , the most common oral symptoms are enanthema $(58.5 \%)$, oral lesions $(48.5 \%)$, dysgeusia $(27.84 \%)$ followed by the sore throat $(25.43 \%)$ followed by. The other common symptoms are and oral bleeding $(22.95 \%)$.

\section{Discussion}

The present systematic review was to find the prevalence of oral manifestations and to suggest the management to those affected with COVID-19. The results based on 10 papers show that sore throat and dysgeusia are the most common oral manifestations. The others include enanthema, oral lesions and bleeding.

\section{Sore throat}

Though sore throat is very common, it can be the result of a nonserious illness to a dangerous one. Sore throat as a sole symptom can be rare as only $5-10 \%$ of COVID-19 patients have it, when in other cases, it is accompanied by other symptoms (Harris, 2021).

\section{Dysgeusia}

Dysgeusia which is the distortion of the sense of taste can be caused by numerous medical conditions like heart disease, Alzheimer's disease, upper respiratory viral infection,etc. (Lozada-Nur, Chainani-Wu, Fortuna \& Sroussi, 2020). Zahra, Iddawela, Pillai, et al., (2020) found that symptoms of dysgeusia are not enough to diagnose an individual with COVID-19, even though it is frequently reported. But if dysgeusia is present for a longer duration, it could lead to an increase in the severity of COVID-19. 


\section{Enanthema}

Enanthema or enanthem is the result of viral infections causingrashes or spots on the mucous membranes. The cause of the symptom might be due to different diseases like chickenpox, measles, hand-foot, and mouth disease, and also COVID-19. Considering the short time in which some COVID-19 patients show enanthema, the symptom suggests a strong association with the virus (Lubell, 2020).

\section{Oral lesions and bleeding}

Oral lesions, gingival inflammation and bleeding or simply are suggested tobe the result of the inflammation initiated by COVID-19 (Froum, 2020). Whereas there are also claims that these manifestations are not the result of viral infection but rather a secondary infection caused by the deteriorating health or medications used for COVID-19 treatment.(Dos Santos, Normando, da Silva, et al., 2020).

\section{Fungal infections}

A few cases were reported related to fungal infection, mostly mucor mycosis as a post covid manifestation. It was mainly found in patients with altered immunity and in patients with pre-existing immunosuppression.

\section{Management}

General manifestations are managed by: Broad spectrum systemic antibiotics (ceftriaxone, doxycycline), antivirals (oseltamivir, favipiravir, remdesivir), antihistamines (Diphenhydramine). The use of fluticasone nasal spray and triamcinolone medications were found to be helpful in the recovery of smell and taste sensation within a week (Singh, Jain \& Parveen, 2021).

Iranmanesh, et al., (2020), Halboub, et al., (2020), andCorchuelo \& Ulloa (2020) observed the various management protocols for oral manifestation of COVID 19 and found that chlorhexidine, an antiseptic mouthwash, is effectively used to reduce the gingival inflammation. Other managements involves application topical or systemic corticosteroids, benzalkonium chloride mouth rinses, normal saline gargling, use of artificial saliva, topical a tifungals (nystatin, oral fluconazole), topical anesthetics (benzocaine 5\% gel).

\section{Conclusion}

Even though enough researches are required to establish a relationship between the oral manifestation and COVID-19, looking out for the oral symptoms might also play a vital role in the timely diagnosis of COVID-19. The surge in the oral manifestations among COVID-19 patients might be the result of the direct effect of virus in the oral cavity, due to secondary infection as a result of compromised immunity or due to adverse reaction of medications used. Therefore, it is important to include dentists in the multi-disciplinary team assisting the COVID- 19 patients so that the clinical dental examination could be accentuated, considering the requirement for support and pain control for the patient and thereby improving their quality of life.

\section{References}

[1]. ANI,Newer covid symptoms you should know. Mint. 2021, April, 10.

[2]. Corchuelo J, Ulloa FC. Oral manifestations in a patient with a history of asymptomatic COVID-19: Case report. Int J Infect Dis. 2020 Nov; 100:154157.Pubmed PMID: 32882435.

[3]. Dos Santos JA, Normando AG, da Silva RL, De Paula RM, Cembranel AC Santos-Silva AR, et al. Oral mucosal lesions in a COVID-19 patient: New signs or secondary manifestations?. Int J Infect Dis. 2020 Aug 1;97:326-8.

[4]. Froum, S. Top 5 oral manifestations of COVID-19. Perio-Impant Advisory.2020, December 3.

[5]. Halboub E, Al-Maweri SA, Alanazi RH, Qaid NM, Abdulrab S. Orofacial manifestations of COVID-19: a brief review of the published literature. Braz Oral Res. 2020 Oct 30;34:e124.Pubmed PMID: 33146320.

[6]. Haseltine, W. A. What Are The 677 Mutations? New Covid-19 Variants Found In The US. Forbes. 2021, February 19.

[7]. Harris, K. (2021, January 22). Is my sore throat COVID-19 or not? [Blog post]. Retrieved from https://www.osfhealthcare.org/blog/is-my-sore-throatcovid-19-or-not/

[8]. How Many New Coronavirus Variants Are There? (2021, March 12). Retrieved from https://www.healthline.com/health/how-many-strains-of-covid-are-there\#bottom-line

[9]. IANS, (2021, February 23). India detects over 24,000 mutations in 7,000 variants of Covid. The Economic Times. https://health.economictimes. indiatimes.com/news/diagnostics/india-detects-over-24000-mutations-in7000-variants-of-covid/81169132

[10]. Iranmanesh B, Khalili M, Amiri R, Zartab H, Aflatoonian M. Oral manifestations of COVID-19 disease: A review article. Dermatol. Ther. 2020 Jan;34(1):e14578.

[11]. Lozada-Nur F, Chainani-Wu N, Fortuna G, Sroussi H. Dysgeusia in COVID-19: possible mechanisms and implications. Oral Surg Oral Med Oral Pathol Oral Radiol. 2020 Sep;130(3):344

[12]. Lubell, J. Is the Presence of Enanthem a Clue for COVID-19?. Medscape. 2020, July 24.

[13]. Pandey, K. How are symptoms of new COVID-19 strains and variants different from original coronavirus?. Timesnownews.com. 2021, April 8.

[14]. Singh CV, Jain S, Parveen S. The outcome of fluticasone nasal spray on anosmia and triamcinolone oral paste in dysgeusia in COVID-19 patients. Am J Otolaryngol. 2021 May 1;42(3):102892.

[15]. World Health Organization. (2020-a, April 23). Coronavirus disease 2019 (COVID-19): Situation Report - 94.

[16]. World Health Organization. Archived: Who timeline-covid-19. 2020-b, April 27.

[17]. World Health Organization. Coronavirus disease (" COVID-19)! 2020-c, November 10.

[18]. World Health Organization. The effects of virus variants on COVID-19 vaccines. 2021

[19]. World Health Organization. (n.d.). WHO Coronavirus (COVID-19) Dashboard. Retrieved April 28, 2021, fromhttps://covid19.who.int/

[20]. Zahra SA, Iddawela S, Pillai K, Choudhury RY, Harky A. Can symptom of anosmia and dysgeusia be diagnostic for COVID-19?. Brain Behav. 2020 Nov;10(11):e01839. 